\title{
Creating shared value through service-learning in management education
}

\author{
NATALIA NiKOLOVA* \\ UNIVERSITY OF TECHNOLOGY SYDNEY
}

PO BOX 123 BROADWAY

NSW 2007 AUSTRALIA

TEL.: +61295143645

E-MAIL: NATALIA.NIKOLOVA@UTS.EDU.AU

LISA ANDERSEN

UNIVERSITY OF TECHNOLOGY SYDNEY SHOPFRONT COMMUNITY

PROGRAM

PO BOX 123 BROADWAY

NSW 2007 AUSTRALIA

TEL.: +6120295142902

LISA.ANDERSEN@UTS.EDU.AU

Paper accepted for publication in the Journal of Management Education, 2017.

* Corresponding author

\begin{abstract}
Service-learning has gained strong interest among educators as a model of experiential education through community engagement. Its potential to contribute to multiple
\end{abstract}


stakeholders, including students, community partners, faculty and university, is well recognized. While research has focused on elements of this teaching model which contribute to the realization of student-related benefits, there has been less emphasis on what aspects enable the creation of shared value to other stakeholders. We describe a postgraduate, elective management consulting course based on service-learning pedagogy which has been running for ten years at the University of Technology Sydney Business School leading to the completion of 75 community projects to date, and evaluate how it creates shared value to multiple stakeholders. We identify four main elements of the course that enable it to deliver value to multiple stakeholders: a dedicated role of client engagement coordinator; a coaching program involving industry experts; student autonomy; and authentic assessments. The main challenges in continuously providing value to all involved parties are: developing focused and realistic project briefs, managing students' commitment and differences in students' skills, and recruiting industry coaches.

Keywords: service-learning; management consulting; experiential learning, work integrated learning

Service-learning is an educational pedagogy that has gained strong interest among educators (e.g., Kenworthy \& Fornaciari, 2010; Yorio \& Ye, 2012). Its potential to contribute to multiple stakeholders is well recognized (e.g., Clayton et al., 2010; Bringle, Clayton, \& Price, 2009). However, while a number of good practice examples on servicelearning in management education have been published (e.g., 2010 Special issue on 
service-learning in the Journal of Management Education; Poon, Chan \& Zhou, 2011; Papamarcos, 2005; Wittmer, 2004; Metcalf, 2010), most of these examples focus on how courses utilizing service-learning provide value to students. We know less about the elements of service-learning design that contribute to the creation of value to other stakeholders, such as community organizations and business schools and universities (e.g., Lester, Tomkovick, Wells, Flunker, \& Kickul, 2005; Grossman, 2002). Yet, service-learning models that create shared benefits and are based on the principle of reciprocity are more effective (Godfrey, Illes, \& Berry, 2005) and enable the development of committed relationships (Dorado \& Giles, 2004) thus ensuring the longterm viability of service-learning models.

\section{Service-Learning in Business Schools}

Service-learning is a "form of experiential education in which students engage in activities that address human and community needs, together with structured opportunities designed to promote student learning and development" (Dumas, 2002, p. 249). Service-learning generates value for students by developing their academic, professional and critical-thinking skills, and civic responsibility (e.g. Yorio \& Ye, 2012; Kenworthy-U'Ren, 2008; Papamarcos, 2005); for community organizations by focusing

on their needs (DiPadova-Stocks, 2005; Bringle \& Hatcher, 2002); and for universities by increasing their legitimacy through contribution to public good (Boyle, 2004).

The advantages of this pedagogical model for students are well supported by prior research (see Yorio and Ye, 2012, and Madsen and Turnbull, 2006 for overviews of research on advantages for students). Andrews (2007), Kenworthy U'Ren (2003) and Kolenko, Porter, Wheatley, and Colby (1996) summarize these advantages under three 
main headings: fostering the personal and intellectual growth of students while imbuing them with a greater sense of social responsibility (see also Yorio \& Ye, 2012).

In contrast to research on the advantages of service-learning for students, the advantages for other stakeholders are not as extensively discussed (Lester et al., 2005). Bortolin (2011) posits this gap is due to a general privileging of the university over the community in these types of partnerships. Giles and Eyler (1998) argue that understanding community impacts of service-learning is one of the top ten unanswered questions in service-learning research (see also Eyler, Giles, Stenson, \& Gray, 2001; Stoecker \& Tryon, 2009).

Service-learning generates value to community organizations when service-learning models meet the needs of community organizations, assisting in the achievement of their goals (Lester et al., 2005). To be of true value to community organizations, the benefits need to exceed the cost of the participation for the community organization (Gray, Ondaatje, Fricker, \& Geschwind, 2000). Godfrey et al. (2005) stress that successful service learning engagement models involve the element of "reciprocity": community organizations work as partners with students and each party contributes knowledge and learns from each other (see also Kenworthy U'Ren \& Peterson, 2005; Kenworthy U'Ren, 2008; Bringle \& Hatcher, 2002).

Service-learning engagement models also create advantages for universities and business schools in the form of "increased legitimacy" (Boyle, 2004). By demonstrating universities' and business schools' contribution to public good, service-learning engagement models are one response to the increasing criticism that higher education promotes learning which is disconnected from practice, leads to the compartmentalization 
of knowledge by discipline, lacks connection to students' personal lives, public issues and the wider community (Dumas, 2002; Godfrey et al., 2005; Khurana, 2010; Papamarcos, 2005), and fails to prepare students for work in highly complex environments (Dallimore, 2002). Service-learning engagement models allow universities and business schools to demonstrate how they contribute to public good by contributing to the community sector as well as by increasing students' awareness of community needs (Boyle, 2004) and lead to enhanced community relations (Eyler et al., 2001).

Despite the many advantages service-learning can generate for students, community organisations and universities, these engagement models don't always deliver upon their promises. Bush-Bacelis (1998) points out that students often find service-learning frustrating because they face high ambiguity and uncertainty in their assignments. According to Madsen and Turnbull (2006), students are sometimes frustrated and discouraged when community partners do not communicate in a timely fashion or when resources (human or material) are not delivered according to their coursework schedule. Kolenko et al. (1996) point out that these conflicts between students and community recipients are a threat to students' learning objectives or the community relationship. In addition, any design of service-learning programs faces the challenge of overcoming the accusation of providing merely "doing without learning" experiences (Kolenko et al., 1996, p. 135). In this way, the concept of service-learning has been criticized for watering down the curriculum and taking time away from traditional academic pursuits (Gray et al., 2000), while others have argued that not all service-learning models create value for students to the same degree (Godfrey et al., 2005). Some engagement models are better suited to broadening students' education breadth and experiences than others. Gray et al. 
(2000) see more positive outcomes when course concepts are tightly linked to students' learning experiences and where the focus is equally on allowing students to develop their academic and professional skills as well as on increasing their understanding of social responsibility.

From the community perspective, common barriers to successful partnerships include inadequate communication and supervision from academic coordinators (Blouin \& Perry, 2009), the short term nature of projects (Stoecker \& Tryron, 2009), and mistmatches between course objectives and the community partner's needs (Sandy \& Holland, 2006).

For Kenworthy-U'Ren (1999) the ability of service-learning courses to deliver benefits to multiple stakeholders depends to a high degree on the course design and implementation (see also Yorio \& Ye, 2012; Andrews, 2007). This indicates the need to identify good practice in service-learning engagement models in business schools, a focus of a 2010 special issue in the Journal of Management Education (Kenworthy \& Fornaciari, 2010).

The aim of this paper is to build upon this special issue and other studies on best practice examples of service-learning (e.g., Poon et al., 2011; Papamarcos, 2005;

Wittmer, 2004; Metcalf, 2010) to present a "how to" template "for practitioners interested in either engaging in service-learning for the first time or refining and expanding their current work in this domain" (Kenworthy \& Fornaciari, 2010, p. 4). While many of the described best practice models of teaching service-learning provide important insights into how to design such courses to deliver on the learning outcomes for students, the course design we describe outlines the elements that enable the creation of shared value for students, community partners, and the business school and university. To do so we 
case study an elective postgraduate management consulting course based on the servicelearning pedagogy that has been offered at the University of Technology Sydney Business School since 2006 and reflect on how the design of the course enables the creation of shared value. The paper shows how service-learning can lead to the development of committed relationships between the community sector, industry partners and universities in which the partners value the relationship beyond specific projects (Dorado \& Giles, 2004; see also Clayton, Bringle, Senor, Huq, \& Morrison, 2010). We reflect on what elements of the course design are critical in delivering that shared value to develop recommendations for other business educators interested in similar educational models.

\section{Methodology}

\section{Approach}

Our methodology is based on a single, longitudinal case-study. Qualitative researchers argue that a single case study provides insight into practice and, where the case represents unusual access to a specific area of interest, it has exemplary value (Eisenhardt, 1989; Yin, 2009; Thomas, 2011). The course we report on represents such a case since both authors have worked on its development and delivery for ten years and use their participant observations, extensive survey data and course materials and documents collected over this extended period of time to analyze and reflect on the elements of the course that facilitate its delivery of value to multiple stakeholders. The longitudinal nature of the case study allows us to report on course challenges and improvements, and their effect on outcomes for various stakeholders (Yin, 2014).

\section{Data collection and analysis}


Participant observation. Participant observation leads to richer data by "subjecting yourself, your own body and your own personality, and your own social situation, to the set of contingencies that play upon a set of individuals" (Goffman, cited in Lofland, 1989, p. 125). We kept detailed notes on the course planning and development complemented with official university documents, such as course outlines, session notes, project lists, student interim and final reports, student emails, student presentations and project logs, students' oral and written feedback including from official university feedback surveys, and clients' oral and written feedback. After each semester we met to discuss insights and lessons learned from the previous semester and to develop ideas for further improvements, which we subsequently piloted and embedded in the course process. For the purposes of this paper, each of us prepared detailed notes on their observations on the course, and coded through student and client feedback to develop insights about the main themes that explain what elements of the course design work well and what are the key challenges. We then compared and discussed these notes and themes during a number of meetings. In this process, we identified students' and clients' perspectives on their experiences and the effects from participating in the course and compared these with our own reflections. We coded stakeholders' perspectives in line with insights we gained from the literature review. In this way, we reduced the data to the following main themes: course set-up, goals, process, benefits, success factors and key challenges. These themes build the basis for the following discussion.

Surveys. Quantitative data was gathered from student, alumni and community client evaluations of the course. In addition to the regular university-wide student feedback survey and course-specific survey sent to students and communit clients, an alumni 
survey was conducted in 2013. In each of the surveys a five point Likert-type scale with (1) being strongly disagree and (5) being strongly agree was used (see also Snell, Chan, Ma, \& Chan, 2015).

The university-wide student feedback survey asks seven course-related questions and one teacher-related question. Between 2009 and end of 2015, 176 surveys have been completed out of the total student population of 313 in this period, a response rate of 56 per cent. ${ }^{1}$ In our custom student survey, we ask students to indicate their level of agreement with ten statements about the quality and significance of their learning experiences in the course. Both surveys include open-ended questions asking students to provide additional reflections on their experiences including what elements of the course they found most or least helpful and, since 2013, what they gained from their interactions with their coach. From 2006 to end of 2015, 171 custom surveys have been completed by students: a response rate of 42 per cent of the total student population of 411 .

The community client survey undertaken by the university's community program asks about the client representative's agreement or disagreement with seven statements related to their experience with the course, the quality of students' work, the opportunity for knowledge exchange, and the usefulness of the project for their organization, and includes additional open-ended questions. From 2006 to end of 2015, 56 client surveys have been completed, 75 per cent of the total number (75) of community clients who

\footnotetext{
${ }^{1}$ We don't have records of the university-wide survey for the period between 2006 -end of 2008 because it was paper-based until 2009.
} 
have participated in the course. ${ }^{2}$ This evaluation sits alongside the client management process, so the team is kept aware of clients' experience throughout the semester.

In 2013 we conducted a survey with course alumni to examine the course's longerterm impact (if any) on their professional and personal development. The survey was sent to alumni who had completed the course between 2006 and 2013. Lester et al. (2005) stress the need to study university alumni in order to provide evidence on whether service-learning has an impact on students after they have completed their degrees. Alumni were asked to indicate their level of agreement with 19 statements related to their assessment of the extent to which the course had an impact on their professional skills, current career and their personal development. The 46 course alumni responses received represented 18 per cent of the total alumni population at that time. ${ }^{3}$

\section{Case Study}

\section{Course description}

The Management Consulting course we report on is a practice-based, block taught course at the University of Technology Sydney Business School involving consulting to community organizations (Figure 1 shows a distribution of projects completed for community sector clients in the course). The aim of the course is consistent with the business school's mission to provide integrative and practice-oriented business education. Similarly to other courses that involve live consulting cases, in this course, "students

\footnotetext{
2 The main reason why the client response rate is not higher is the lack of resources to follow up with individual survey respondents. From 2016 the evaluation survey is managed through an online system that tracks respondents and can automatically send reminders.

${ }^{3}$ The number of possible responses is constrained by the limited availability of up-to-date contact information for past students.
} 
apply previously learned topics to an unstructured problem with intentionally limited guidance from the instructor, and...seek out and learn methodological techniques on an as-needed basis" (Gorman, 2011, p. 565). Community clients are sourced through the university community engagement program, UTS Shopfront, which was set up 20 years ago as a cross-disciplinary initiative to strengthen university and community collaboration. It works with academics and students from all faculties.

\section{INSERT FIGURE 1 ABOUT HERE}

The collaboration with the business school in the Management Consulting course commenced in 2006. The course is an elective in the MBA and other Masters programs offered at the business school and involves a mix of part-time, local students and fulltime, international students. Depending on student enrolment, we complete between three to six projects per semester, with four to six students per team. ${ }^{4}$ Until end of 2015,75 projects have been completed. This equates to more than $\$ 1.8$ million (AUD) in pro-bono consulting provided to the nonprofit sector. ${ }^{5}$

The Management Consulting course has been designed to resemble a typical consulting engagement (see also Gorman, 2010). Students complete a team-based

\footnotetext{
${ }^{4}$ The course was offered once yearly until end of 2010. Since 2011, due to strong demand from students and community organizations, it has been offered twice yearly.

${ }^{5}$ The pro-bono value formula was developed in response to requests from community clients (particularly international development NGOs) to include the project contribution in their own reporting. It is critical that the formula does not over-claim value, so it is deliberately designed to deliver a very conservative estimate of value based on median hours and basic allowed salaries. Each project is valued as the sum of:

- Academic supervisor at 18 hours per project;

- Community engagement coordinator at 18 hours per project;

- Each student team member at 100 hours per project (median) with salary calculated at the university's mandated basic rate for the most junior research assistant;

- Since 2013, when the coaching program began, industry coaches have been added to the formula at AUD $\$ 1500$, to account for the 10 hours commitment asked of them, which is significantly less than their professional fee.
} 
consulting project for a community based organization. Class sessions are scheduled over five full days spread over 13 weeks (the duration of one semester) in resemblance to the typical project milestones in a consulting project, with additional meetings and feedback taking place throughout the semester as needed. Student assignments are designed to replicate typical consulting deliverables: project proposal consisting of project scope and project methodology (30\% of the total mark, group-based); final report (50\% of the total mark, each student is responsible for one section of the final report and marked individually) and final client presentation (20\% of the total mark, marked individually). Figure 2 outlines key activities, assessments and feedback points.

\section{INSERT FIGURE 2 ABOUT HERE}

In 2013, we introduced a coaching program with industry experts (current or former consultants) providing guidance and feedback to a student team. Since then, 39 coaches have participated in the coaching program. They have come from a number of large, international consulting companies as well as from smaller, Australian-based consultancies; 15 per cent of the coaches have been university alumni. Since 2015 , we have been working on developing a partnership with two large consulting companies.

\section{Course process}

Pre-semester, the community engagement coordinator begins a process of recruiting 'student-ready' projects from community organizations based on their needs. Table 1 provides detail on each of the stages and elements of the course design.

\section{INSERT TABLE 1 ABOUT HERE}


During the first day session, after introducing the course, its pedagogical background and course process, students select team leaders and build teams. Students then receive the prepared briefs on all available projects and pitch for projects for which they have appropriate skills as well as personal interest. After project allocation to teams, students are introduced to the consulting process and analytical tools, such as issue and hypothesis trees. Advice is provided on how to prepare for the first client meeting and on the format and expectation of their first deliverable/assessment, the consulting proposal. Students then have about five to ten days before their first client meeting. In this time, they meet with their industry coach where possible. During their first client meeting, with the facilitation of the community engagement coordinator, students discuss the project brief and work on its further refinement. Students also sign a confidentiality agreement.

Two weeks after Day One, student teams present a project scope to the academic supervisor (Day Two), after discussing it with their project coach. The scope document is the first group assessment and an opportunity for the team to receive early feedback on how well they are meeting expectations. Students then incorporate the received feedback and submit the revised scope document to the client representative for an official sign-off. Also in Day Two, students are introduced to the specifics of the non-profit sector and management of community organizations by an expert from academia or industry. The academic supervisor discusses a number of consulting-specific frameworks and methodologies and how these can be used for the delivery of the agreed project objectives. Examples from previous semesters are used as a demonstration of how such tools can be used for the development of insights. Students are provided with an 
extensive slide deck/consulting 'toolkit', which the course coordinator regularly reviews and extends in consultation with practicing consultants.

In their next class session (Day Three), students present the project methodology to the academic coordinator to explain how they will deliver on the objectives of the project that were agreed in the project scope. To do so, students need to decide on appropriate data collection and analysis methods/tools. The coach provides valuable feedback on what tools and methods might work best to deliver on the project scope. Students also present a work plan they use for project management. The academic supervisor discusses data interpretation and explains how reports must be structured and designed.

After feedback on and assessment of their methodology, students commence data gathering, analysis and the development of recommendations. During this period, teams meet several times with their client and coach, as well as with the academic supervisor and community engagement coordinator. Three weeks prior to the final presentation and report delivery, students submit a draft project report for feedback to their coach, the community engagement coordinator and the academic supervisor. Day Four is used for updates on project progress and preparing the students for the delivery of their final report and presentations. Additional material is presented based on students' interests (e.g., on managing the client-consultant relationship or starting a career in consulting).

After incorporating the received feedback, students send their final reports with recommendations and implementation plan to their client one week before the final presentations. The final presentations on Day Five take place in a board-room style environment with the students presenting their recommendations to clients' staff and 
board, academic supervisor, community engagement coordinator and, often, the industry coaches. Clients are encouraged to ask questions and to comment on the student work.

\section{Course benefits}

Benefits for students. In support to prior research that has assessed student satisfaction with service-learning (e.g., Yorio \& Ye, 2012; Gray et al., 2000), the university student feedback survey and our custom course survey both demonstrate high levels of student satisfaction with the course. This is further confirmed by the results from the last two semesters when we were allowed to include two course-specific questions to the standard survey (see Table 2 and 3).

\section{INSERT TABLE 2 ABOUT HERE}

\section{INSERT TABLE 3 ABOUT HERE}

In line with previous research on service-learning (e.g., Andrews, 2007; Kenworthy U'Ren, 2003), we found that students particularly value the relevance of the course for their professional and personal development. Regarding professional development, students appreciated the opportunity to learn consulting skills and to put theoretical concepts and knowledge they have obtained during their studies into practice: 'Work on a real case and believe that you can make an impact using what you've learned during the MBA is the best approach one can expect from [university education].' Such experiences increase students' chances of finding a job. This is much appreciated by our international students as the course enables them to gain working experience in Australia.

Students further commented on the relevance of the course for their personal development. Students appreciated the development of their organizational, 
communication and team working skills. Many students commented that their experiences in the course developed their social responsibility, as demonstrated by the following comment: 'This project opened my eyes about how important it is to be involved and working for a non-profit organisation.'

Our alumni survey showed that students positively assessed the course contribution to their professional and personal development in retrospect (see Table 4). Most alumni felt that the skills they learned in the course were important for their current employment and increased their employability, because, as one alumni put it, 'by telling the real experience I had in working through the project, I always increased the attention during a job interview.' Some alumni have continued their engagement with their community organizations 'beyond the course', as board members or in other voluntary or advisory capacities.

\section{INSERT TABLE 4 ABOUT HERE}

Benefits for clients. The community clients provide an overwhelmingly positive assessment of students' professionalism and the value received through the students' work. Over 90 per cent of community clients reported high satisfaction with the students' work and outcomes and many organizations apply for follow-up projects (see Table 5). Client feedback demonstrates three key benefits. First, clients greatly appreciated the access to a high quality, independent advice. As our clients are all small community organizations (from volunteer-run organizations to organizations with a small number of professional staff), they do not have the financial resources to buy professional consulting advice. As one client explained, 'I found the experience and outputs to be tremendously 
beneficial. It's very difficult for a small, community based organisation to fund and therefore get access to management consulting support.'

\section{INSERT TABLE 5 ABOUT HERE}

Second, client organizations appreciated the clarity and efficiency of the engagement process: 'The process was easy to follow and it was very clear from the start what was expected of us.' This aspect is particularly important to our clients as they have very limited resources and therefore need to carefully consider how they use their time.

Third, clients commented on the usefulness and value of the outcomes they received. Clients appreciated that they were provided with in-depth data and insights that they could use in their planning and operations, as explained by one client: 'the team made nine very sage, creative recommendations - based on a comprehensive best practice research and analysis - that were well matched to our 'start up' personnel and financial capacity, but equally were very strategic and value adding - just excellent!' Specific deliverables include communication plans, volunteer recruitment templates, risk management assessment tools, etc. that can be directly used in the client organizations and are also useful in clients' engagement with external stakeholders. As one client explained, 'We have used the student project to demonstrate our commitment to improve our product to our stakeholders, including clients and investors.'

Benefits for the business school and the university. The main value generated by servicelearning programs for universities consists in increased legitimacy: service-learning engagement models allow universities to demonstrate their contribution to public good by supporting the community sector as well as by increasing students' awareness of community needs (Boyle, 2004, 2007). This also contributes to the reputation of business 
schools and universities (Vidaver-Cohen, 2007). In the case we report on, the business school and the university include information on completed projects, including the probono value of these projects, in quality reporting: in the annual report to the United Nations on the implementation of the Principles for Responsible Management Education (UNPRME) and the university annual Social Justice report. Course data is included in global rating/ranking submissions, such as QSStars. Information on projects is often published in internal and external publications. In addition, client recommendations generate follow up projects in other disciplinary areas, such as design, IT and communications, creating further opportunities for service-learning across faculties.

Benefits for industry coaches. Coaches see value from their involvement in the course as they use their skills and knowledge to contribute to the university and the community, i.e. as part of their social responsibility. For some coaches, involvement provides an opportunity to develop their coaching skills in a 'safe environment'. In several cases, two coaches have worked in tandem on the same project where the more experienced coach supports the less-experienced coach to hone their coaching skills.

\section{Lessons learned}

Based on our experience in teaching the Management Consulting course over 10 years as well as on the feedback received from students, clients and industry advisors, we reflect below on the main elements that contribute to its success in providing benefits to multiple stakeholders, and outline the key challenges.

\section{Critical elements of course design}


First, having a dedicated role to select clients and manage the client engagement process is critical in ensuring positive benefits for both students and clients. Based on our experience, it is important that the client engagement coordinator assists clients in clarifying their needs, ensures that their expectations are realistic and achievable and makes the engagement process straight-forward and efficient. An important part of the role is ensuring that clients are committed to the projects by discussing their needs and expectations. To fulfil this role well, the person taking on this role needs to have in-depth understanding of the community sector so they are able to provide feedback and support to student teams in scoping the project and understanding clients' needs (see also Bringle and Hatcher, 2002 who affirm the importance of ongoing feedback). The following client comment demonstrates the importance of this role: 'I found [the community engagement coordinator] of most help assisting us refine the scope into a manageable and focus brief that the project team could reasonably deliver on. That sort of pragmatism and understanding of what is reasonable and achievable really helps ensure success.' Additionally, as projects often generate follow-up projects undertaken by students in other disciplinary areas, a centralized unit managing the relationship with community organizations enables stewardship of that follow-up activity, leading to greater benefit to the community partner and to the university (see also Bringle \& Hatcher, 2002).

The second critical element of the course design is the offer of additional professional support, guidance and feedback to students by collaborating with industry professionals. In our case, the responsibility of the coach is to guide students in the application of problem solving tools and techniques, in the interpretation of data, the development of recommendations and the writing up and presentation of the results. Thus, we 
recommend that industry advisors have sufficient consulting or other relevant experience (e.g., they have at least 3 years consulting experience) in order to be able to execute the role successfully. The importance of being able to interact with and learn from industry experts is recognized by students, as demonstrated by the following comment:

The coaches were very helpful. They have given very specific and constructive feedback on how to go about in the research and the report itself...[From my interactions with the coach] I gained the perspective of a real consultant and how they really go about their research on a particular project.

By assisting students' learning, coaches support the development of good outcomes for client organizations, as demonstrated by the following comment:

At one point the team had a conflicting view point about one of the recommendations proposed. [The coach] stepped in to resolve this conflict through basic logic and explanation...This was very valuable and helped put the team back at ease...I think the coaching program is critical and engaging...The coach does bring in skills, experience and qualities that are key to supporting both the students and the client.

Annother model of industry support that other insitutions might consider is the creation of an industry advisory council which can enable experienced senior professionals to engage meaningfully with the university. These professionals can be asked to provide further feedback to students in a rehearsal session before students are due to present their recommendations to their clients. Whatever the chosen method of providing further assistance through industry professionals, the inclusion of such additional feedback and support mechanisms can greatly support student learning and the creation of quality outcomes for clients, and contributes to the reputation of universities 
for providing industry-relevant education and skills development (see also Schlee, 2000). Such programs further enable industry professionals to provide meaningful contributions to universities, thus strengthening universities' relationships with industry.

The third critical element in the course design is building in sufficient autonomy which fosters motivation and accountability while providing the necessary support to ensure that students don't feel overwhelmed. Such a learning environment leads to higher levels of motivation and achievement (Debnath et al., 2007; Wellington et al., 2002) resulting subsequently in better outcomes for clients. For example, our experience demonstrates that it is important to give students some autonomy in building teams, while at the same time, ensuring that teams have diverse skill sets as required by the specific projects. A part-steered/part-self-determined team-building process ensures that teams have a range of relevant skills and experiences to address the client brief, while increasing students' commitment to their team and their client, and enthusiasm for doing the project (see Table 1 where we describe our approach to team building). As one student explained, 'the team selection process was positive; I wasn't sure that we would have the opportunity to build a team that suited our strengths but the nominated leader did this well. I learnt more from being forced into a cross functional team than playing to my strengths.'

Students have autonomy in scoping the project brief, deciding on what methodologies and tools they will use to collect and analyze data, what recommendations they will suggest and how to best design and present their messages (see also Wellington et al. 2002). They receive multiple feedback to each of these steps from the course coordinator, the community engagement coordinator and the coaches, however, ultimately, it is their responsibility to decide how best to use this feedback. Having this autonomy is greatly 
appreciated by the students, as it enables their learning: 'The autonomy provided in the [course] was really unique. It gave me an opportunity to learn 'on-the-job' (in a clientrelationship context) while also benefiting from the comfort of the classroom where it is possible to fail and learn from it.'

Students are comfortable to perform autonomously because of the multiple layers of support and feedback, as commented by one student: 'Every possibility of assistance was provided [in the course] whilst still allowing for us to complete the tasks ourselves. Facilitators, guest speakers, [community engagement coordinator] and client were carefully thought out... and [provided] material to help us learn.'

Our experience shows that building in regular and multifaceted feedback in such courses can increase students' motivation and learning, and leads to better outcomes for client organizations. At the same time, this requirement reduces the number of projects and students that can be appropriately supported. We have found that to ensure benefits for all stakeholders, we can not support more than 6 projects (with a maximum of 36 students) per semester.

The fourth critical element of the course design we identified is the authentic design of assessments. The three course assessments (project proposal, final report and final presentation) are designed to replicate consultant deliverables to clients, and we continuously emphasize that clients, not the academic assessor/coordinator, are the primary audience for the assignments. Providing authentic assessments (see also Svinicki 2004; Wellington et al., 2002) greatly increases students' motivation to perform to the best of their abilities, as demonstrated by the following comment: 
The fact our projects had a bearing on a real organization rather than being purely academic meant that 'the stakes were higher'. Whilst this did cause a certain level of anxiety at times it caused us to think as professionals rather than just as students... [I liked] the fact that we got to work with a real organization and that our recommendations could have genuine implications for both [our client] and for the cancer [not for profit] sector more broadly.

Knowing that their assessments can make a significant contribution to their clients was seen by many students as 'personally fulfilling': 'The experience of helping a disadvantaged and under resourced community organization which performs valuable work for people living with disabilities was very motivating and personally fulfilling.' The 'task significance' of all assessment therefore greatly contributed to students' motivation and satisfaction (see also Debnath et al., 2007) consequently leading to quality outcomes for clients.

Evaluation strategies are an important element of designing authentic assessments (Wellington et al. 2002). We use criterion-based assessment, observations of student interactions, students' self-assessment and client feedback when evaluating individual and group performance. All assignments are assessed based on their quality, relevance to clients and their level of professionalism by using specifically designed assessment rubrics. The assessment strategy takes into account the level of positive impact on the client organizations (see also Kenworthy, 2010) thus reinforcing the authenticity of the assessments. In line with this, we ask students to self-assess their performance as a team in Day 2, 3 and 4. The academic coordinator discusses the team's perception of how well 
they are working as a team and encourages students to develop strategies how to address any issues, which gives students further accountability.

\section{Course challenges}

Despite the very positive assessment of the course, it is important to reflect on the most significant challenges we have experienced in order to assist colleagues who might seek to adopt elements of this model. One of the main challenges is to develop a clear brief for the students and to agree on a project scope that will add value to the client and is achievable and realistic in the timeframe students have to deliver their recommendations. As one student described: 'While we tried to manage the client expectations, [in] each meeting with him, he kept attempting to change the project scope.' Most community clients have a range of issues they need assistance with and often request additional tasks to be completed even after the project scope has been agreed upon. This requires a very careful management of both the expectations of the community clients and those of the students. Having an experienced professional as community engagement coordinator who engages clients pre-semester to discuss their needs contributes to the development of relevant and realistic project briefs. 'Scope creep' is further managed through the project scope assignment which ensures that coach, academic coordinator and community engagement coordinator all provide feedback on the scope to guard students from overcommitting. No scope changes are accepted after the project scope has been agreed upon (with only a few exceptions when there has been a change in the circumstances of the client or the student team). Clients with a range of issues that cannot be addressed in one project are invited to undertake a project in future semesters. 
Linked to this challenge is managing students' commitment given the greater-thanaverage student workload for this course. As students usually take two to three other courses at the same time, and many of the students work part-time or casually, committing additional time to this course beyond what students normally expect, is a major issue. One student described how, 'as a part time student with a full time job the workload was challenging. This is not a [course] that should be taken lightly and if students think they can take it easy this is not the [course] for them.' While finding time for team meetings has been identified as a challenge to performing group work goals in other settings (Rafferty, 2013), in our case, the challenge is further increased due to the nature of the group task. To address this challenge, we explain in detail the commitment needed to undertake a project with a real client in pre-semester communications and on Day One of the course. Setting the expectations clearly and early on is critical in order to avoid later challenges by students. As one student wrote, the teaching team 'had clearly articulated their expectations of the project team.' In addition, at the first meeting with the community client, the community engagement coordinator consciously fits the available time of the students and their teams' skills and knowledge against the expectations of the client to define a manageable scope. This student comment is a typical reflection on that support: '[The community engagement coordinator] had given support when required and helped facilitate first contact with the client, which I think personally was very important.' An alternative option is to design such a course as the capstone for a program, thus allowing more time for the completion of the course, and possibly granting students double credit points. 
A third major challenge arises when students have very different skills and levels of prior knowledge and experience. This can create conflicts within student teams when more experienced students feel that they take on a larger workload, while less experienced students rely on others to deliver on their tasks. As one student said, '[t]here were people in my team with a range of skills and English levels who could not adequately contribute to the project. This doubled the workload for me. The [course] should be stricter about criteria for joining [it].' To manage this challenge, when enrolling into the course, students are advised that the course is recommended for students with very good English language skills. The issue is further managed through the team building process which ensures that each team equally consists of more and less experienced students. Another option colleagues might consider to address this challenge is to ask students to 'apply' for the course and select only students who have the necessary skills and experience to develop high-quality outcomes for clients.

Because of skills' differences and increased time commitment required, 'free-riding' is always a challenge. Thus, it is important to monitor how individual students interact with their team members during the formal in-class sessions and through informal communications with teams throughout the semester. Workload and roles need to be equally distributed within teams. Our experience demonstrates that any commitment issues need to be pro-actively addressed early on to maximize the positive outcomes for students and clients. The self-assessment process we describe above provides opportunities for addressing such issues early on. In contrast, an end-of-semester peer assessment, which we trialed for a few semesters, does not contribute to that end (see also Rafferty, 2013). 
The fourth major challenge is recruiting industry coaches who have the time and motivation to support student teams. While many professional consultants have been interested to participate in the program, not all of them have had the time to do so meaningfully. For example, one student wrote, '[p]roblem was that the coaches appointed were from other cities thus reducing our means of contact to video calling. This really came to hinder us in the later stage of the project as we could not have face to face meeting with them.' Students expecting greater contribution against what is actually possible from a busy coach can lead to disappointment. To manage this challenge, coaches are provided with an overview of the course with its aims, assessments and process, expected contributions and time commitment for coaches, and the course coordinator meets with coaches pre-semester to explain the purpose of the course and the expectations on the role. ${ }^{6}$ We ask coaches to carefully consider the amount of time they are able to commit, and to communicate their availability early on to the student team to avoid unrealistic expectations. Where possible, we encourage coaches to work in pairs to spread the time commitment. Developing a partnership with one or two larger consulting firms which would see their ongoing contributions to the course as part of delivering against their corporate social responsibility KPIs and/or as a contribution to the university can help address this challenge (see Schlee, 2000 for suggestions on the recruitment of mentors).

\section{Discussion and limitations}

Service-learning has been increasingly recognized as a valuable pedagogical approach to immerse students "in some of the most difficult and complex organizational

\footnotetext{
${ }^{6}$ We are happy to share this document with colleagues who might want to put in place a similar program. Please contact the authors directly to request a copy of the document.
} 
environments in existence today" (Kenworthy U'Ren, 1999, p. 385) while enabling students to gain new knowledge and develop their professional skills (e.g., Yorio \& Ye, 2012; Papamarcos, 2005). In addition to students, other stakeholders, such as community organizations and universities share the value from this learning model (e.g., Clayton et al., 2010; Bringle et al., 2009). However, service-learning is not without its challenges. For example, students often resist participation in service-learning courses as they don't see the relevance for their business education (Kolenko et al. 1996) or resent the increased time commitment required for these 'real' projects (Clayton et al., 2010).

Our experience over ten years shows that to offer successful service-learning models, it is important that academics are provided with additional resources to be able to successfully manage the needs and expectations of students, community clients, the university and industry experts to enable shared value creation (see also Eyler et al., 2001). As Kenworthy-U'Ren (2008, p. 819) remarks, “[o]ne of the difficulties of servicelearning is the fact that it requires commitment and involvement from multiple stakeholders." Committing additional resources, such as establishing the role of a community engagement coordinator and possibly an industry engagement coordinator (to build and manage the relationship with potential coaches), is a worthwhile investment for universities given the wide-ranging benefits such courses create (see our discussion on course benefits). In our experience, the ongoing collaboration between a business school academic and the community engagement coordinator builds "the hub of the wheel" (Kenworthy-U'Ren, 1999) and is critical for the success and continuation of such courses (see also Kenworthy-Uren, 2003), alongside with a valorization of the course's achievements at a senior university level (see also Godfrey et al., 2005). 
This paper also contributes to research on service-learning by demonstrating the benefit of introducing coaching by industry professionals to student teams involved in service-learning. While there is some research on the benefits and design of coaching/mentoring programs in business schools (e.g., Schlee, 2000), to our knowledge, how coaching/mentoring by industry professionals can contribute to the quality of service-learning courses in business schools has not been explored. Our experience demonstrates that providing students with the opportunity to be coached by industry professionals can lead to a number of benefits: it supports the development of students' professional skills and networks, leads to higher quality outcomes for the community clients and contributes to strengthening the relationship between universities and industry. As finding and recruiting available and committed industry experts is challenging, one way forward, from our experience, is to develop an ongoing partnership with a few larger consulting companies prepared to 'take on' the recruitment process internally as part of a commitment to corporate social responsibility.

Being based on a single case study (a single course at a single institution), our paper has limitations related to the single case study methodology (see Gerring, 2004 for an overview). The longitudinal and in-depth nature of our case study can, however, shed some light on the elements of course design that lead to benefits to multiple stakeholders. Further research on service-learning approaches which adopt all or some of the design elements discussed above is needed in order to confirm the impact of these elements on achieving benefits for multiple stakeholders in different contexts, and how these elements interact (e.g., Gerring, 2004). Another limitation is that our insights might be less relevant for programs involving students with no working experience. A key factor enabling the 
achievement of shared value to all stakeholders in our case is that most students

completing the course have at least some working experience thus enabling teams to provide valuable and realistic solutions to clients' challenging real-life problems.

\section{Conclusion}

Our paper sought to shed light on the elements of course design based on service-learning pedagogy which contribute to the creation of shared value for multiple stakeholders - the students, community organizations, the university and industry professionals. We suggest that to do so, all parties need to be committed to the creation of shared value: students need to commit additional time and be truly motivated to develop outcomes that will be valuable to their community client; clients need to commit to interact with the student team, share relevant information and provide feedback; industry professionals need to volunteer time and share their experience to support students' learning and enable quality outcomes; and the academic team needs to take on a role that goes beyond the 'standard' teaching role which requires additional time commitment to select and help scope projects, manage student teams, build relationships with industry professionals and monitor and report achievements to the university. 


\section{References}

Andrews, C. P. (2007). Service learning: Applications and research in business. Journal of Education for Business, 83(1), 19-26.

Bershon, J. S. (1994). A marriage made in heaven: Community colleges and service learning. Community College Journal, 64(6), 14-19.

Blouin, D. D., \& Perry, E. M. (2009). Whom does service learning really serve? Community-based organizations' perspectives on service learning. Teaching Sociology, 37(2), 120-135.

Bortolin, K. (2011). Serving ourselves: How the discourse on community engagement privileges the university over the community. Michigan Journal of Community Service Learning, 18(1), 49-58.

Boyle, M. E. (2007). Learning to neighbor? Service-learning in context. Journal of Academic Ethics, 5(1), 85-104.

Boyle, M. E. (2004). Walking our talk: Business schools, legitimacy, and citizenship. Business \& Society, 43(1), 37-68.

Bringle, R.G., \& Hatcher, J.A. (2002) Campus-community partnerships: The terms of engagement. Journal of Social Issues, 58(3), 503-516.

Bringle, R. G., Clayton, P. H., \& Price, M. F. (2009). Partnerships in service learning and civic engagement. A Journal of Service Learning \& Civic Engagement, 1(1), 1-20.

Bush-Bacelis, J. L. (1998). Innovative pedagogy: Academic service-learning for business communication. Business Communication Quarterly, 61(3), 20-34. 
Clayton, P. H., Bringle, R. G., Senor, B., Huq, J., \& Morrison, M. (2010). Differentiating and assessing relationships in service-learning and civic engagement: Exploitative, transactional, or transformational. Michigan Journal of Community Service Learning, 16(2), 5-22.

Dallimore, E. J., \& Souza, T. J. (2002). Consulting course design: Theoretical frameworks and pedagogical strategies. Business Communication Quarterly, 65(4), 86-101.

Debnath, S. C., Tandon, S., \& Pointer, L. V. (2007). Designing business school courses to promote student motivation: An application of the job characteristics model. Journal of Management Education, 31(6), 812-831.

DiPadova-Stocks, L. N. (2005). Two major concerns about service-learning: What if we don't do it? And what if we do? Academy of Management Learning \& Education, 4(3), 345-353.

Dorado, S., \& Giles Jr, D. E. (2004). Service-learning partnerships: Paths of engagement. Michigan Journal of Community Service Learning, 11(1), 25-37.

Dumas, C. (2002). Community-based service-learning: Does it have a role in management education? International Journal of Value-Based Management, 15(3), 249-264.

Eisenhardt, K. M. (1989). Building theories from case study research. Academy of Management Review, 14(4), 532-50.

Eyler, J., Giles Jr, D. E., Stenson, C. M., \& Gray, C. J. (2001). At a glance: What we know about the effects of service-learning on college students, faculty, institutions and 
communities, 1993-2000. $3^{\text {rd }}$ ed. Vanderbilt University. Retrieved from:

https://www.mnsu.edu/cetl/academicservicelearning/Service-Learning.pdf.

Gerring, J. (2004). What is a case study and what is it good for? American Political Science Review, 98(02), 341-354.

Giles, D. E., Jr., \& Eyler, J. (1998). A service-learning research agenda for the next five years. In R. Rhoads \& J. Howard (Eds.), Academic service-learning: A pedagogy of action and reflection. New directions for teaching and learning (pp. 65-72). San Francisco: Jossey-Bass.

Godfrey, P. C., Illes, L. M., \& Berry, G. R. (2005). Creating breadth in business education through service-learning. Academy of Management Learning \& Education, 4(3), 309-323.

Gorman, M. F. (2010). The University of Dayton operations management capstone course: Undergraduate student field consulting applies theory to practice. Interfaces, 40(6), 432-443.

Gray, M. J., Ondaatje, E. H., Fricker Jr, R. D., \& Geschwind, S. A. (2000). Assessing service-learning: Results from a survey of "Learn and serve America, Higher Education". Change: The Magazine of Higher Learning, 32(2), 30-39.

Grossman Jr, T. A. (2002). Student consulting projects benefit faculty and industry. Interfaces, 32(2), 42-48.

Kenworthy, A. L., \& Fornaciari, C. (2010). No more reinventing the service-learning wheel. Presenting a diverse compilation of best practice "How to" articles. Journal of Management Education, 34(1), 3-8. 
Kenworthy-U'Ren, A. L. (2008). A decade of service-learning: A review of the field ten years after JOBE's seminal special issue. Journal of Business Ethics, 81(4), 811-822.

Kenworthy-U'Ren, A. (2003). Service-learning and negotiation: Engaging students in real-world projects that make a difference. Negotiation Journal, 19(1), 51-63.

Kenworthy-U'Ren, A. L. (1999). Management students as consultants: An alternative perspective on the service-learning “call to action". Journal of Management Inquiry, 8(4), 379-387.

Kenworthy-U'Ren, A. L., \& Peterson, T. O. (2005). Service-learning and management education: Introducing the "WE CARE" approach. Academy of Management Learning \& Education, 4(3), 272-277.

Khurana, R. (2010). From higher aims to hired hands: The social transformation of American business schools and the unfulfilled promise of management as a profession. Princeton University Press.

Kolenko, T. A., Porter, G., Wheatley, W., \& Colby, M. (1996). A critique of service learning projects in management education: Pedagogical foundations, barriers, and guidelines. Journal of Business Ethics, 15(1), 133-142.

Lester, S. W., Tomkovick, C., Wells, T., Flunker, L., \& Kickul, J. (2005). Does servicelearning add value? Examining the perspectives of multiple stakeholders. Academy of Management Learning \& Education, 4(3), 278-294.

Lofland, L. H. (1989). On fieldwork. Erving Goffman. Journal of Contemporary Ethnography, 18(2), 123-132. 
Madsen, S. R., \& Turnbull, O. (2006). Academic service learning experiences of compensation and benefit course students. Journal of Management Education, 30(5), 724-742.

Metcalf, L. E. (2010). Creating international community service learning experiences in a capstone marketing-projects course. Journal of Marketing Education, 18, 1-17.

Papamarcos, S. D. (2005). Giving traction to management theory: Today's servicelearning. Academy of Management Learning \& Education, 4(3), 325-335.

Poon, P., Chan, T. S., \& Zhou, L. (2011). Implementation of service-learning in business education: Issues and challenges. Journal of Teaching in International Business, 22(3), 185-192.

Rafferty, P. D. (2012). Group work in the MBA classroom: Improving pedagogical practice and maximizing positive outcomes with part-time MBA students. Journal of Management Education, 37(5), 623-650.

Sandy, M., \& Holland, B. A. (2006). Different worlds and common ground: Community partner perspectives on campus-community partnerships. Michigan Journal of Community Service Learning, 13, 30-43.

Schlee, R. P. (2000). Mentoring and the professional development of business students. Journal of Management Education, 24(3), 322-337.

Snell, R. S., Chan, M. Y. L., Ma, C. H. K., \& Chan, C. K. M. (2014). A road map for empowering undergraduates to practice service leadership through service-learning in teams. Journal of Management Education, 39(3), 372-399. 
Stoecker, R., \& Tryon, E. (2009). The Unheard Voices: Community Organizations and Service Learning. Philadelphia: Temple University Press.

Thomas, G. (2011). A typology for the case study in social science following a review of definition, discourse, and structure. Qualitative Inquiry, 17(6), 511-521.

Vidaver-Cohen, D. (2007). Reputation beyond the rankings: A conceptual framework for business school research. Corporate Reputation Review, 10(4), 278-304.

Wellington, P., Thomas, I., Powell, I., \& Clarke, B. (2002). Authentic assessment applied to engineering and business undergraduate consulting teams. International Journal of Engineering Education, 18(2), 168-179.

Wittmer, D. P. (2004). Business and community: Integrating service learning in graduate business education. Journal of Business Ethics, 51(4), 359-371.

Yin, R. K. (2009) Case study research: Design and methods (Vol. 5), 4th ed. Thousand Oaks, California: SAGE Publications.

Yin, R.K. (2014) Case study research design and methods. SAGE Publications, Thousand Oaks, CA.

Yorio, P. L., \& Ye, F. (2012). A meta-analysis on the effects of service-learning on the social, personal, and cognitive outcomes of learning. Academy of Management Learning \& Education, 11(1), 9-27. 
Figure 1: Projects by community sector: 2006 to 2015

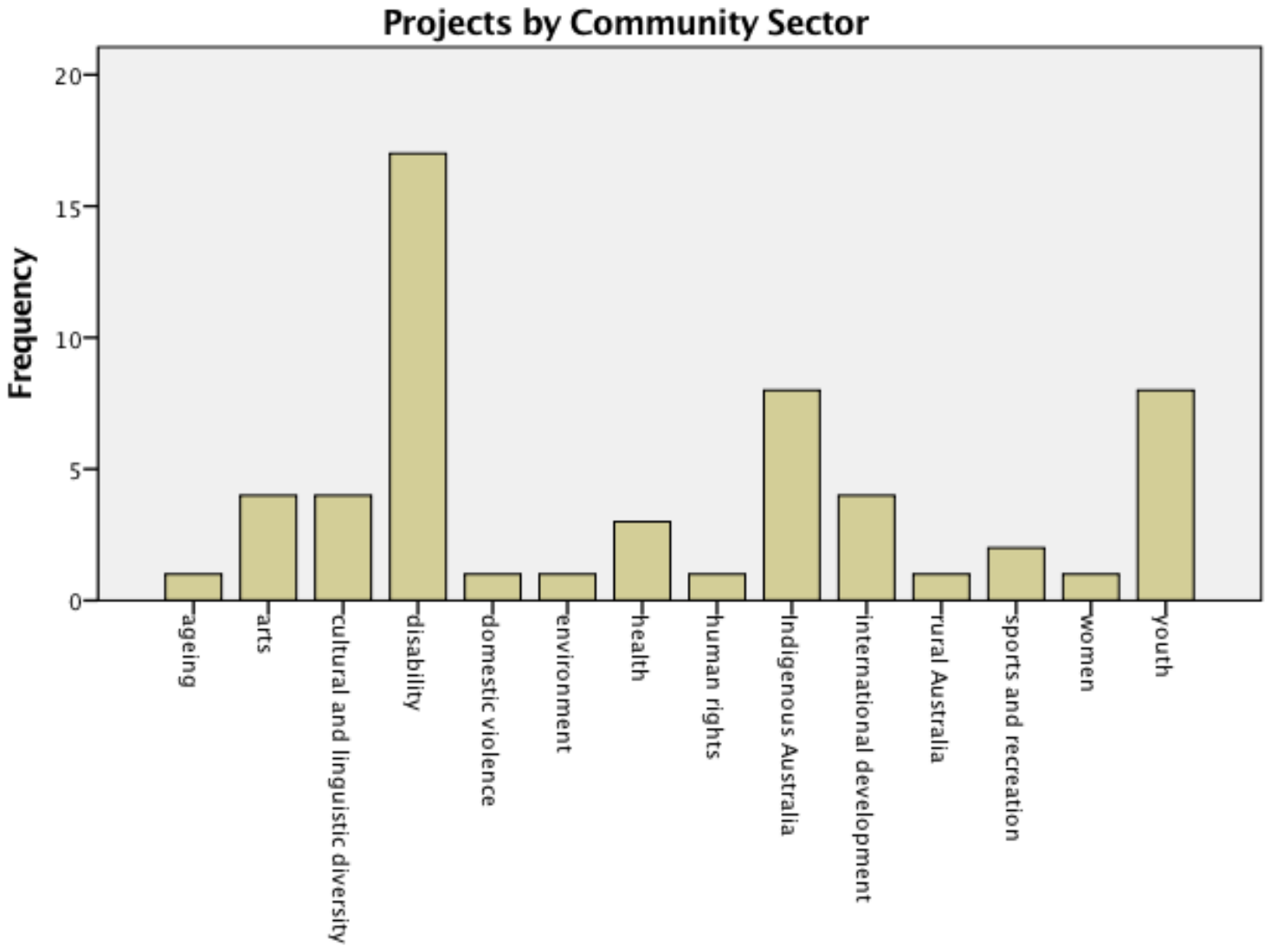




\section{Figure 2: Consulting project process, key dates and assessments}

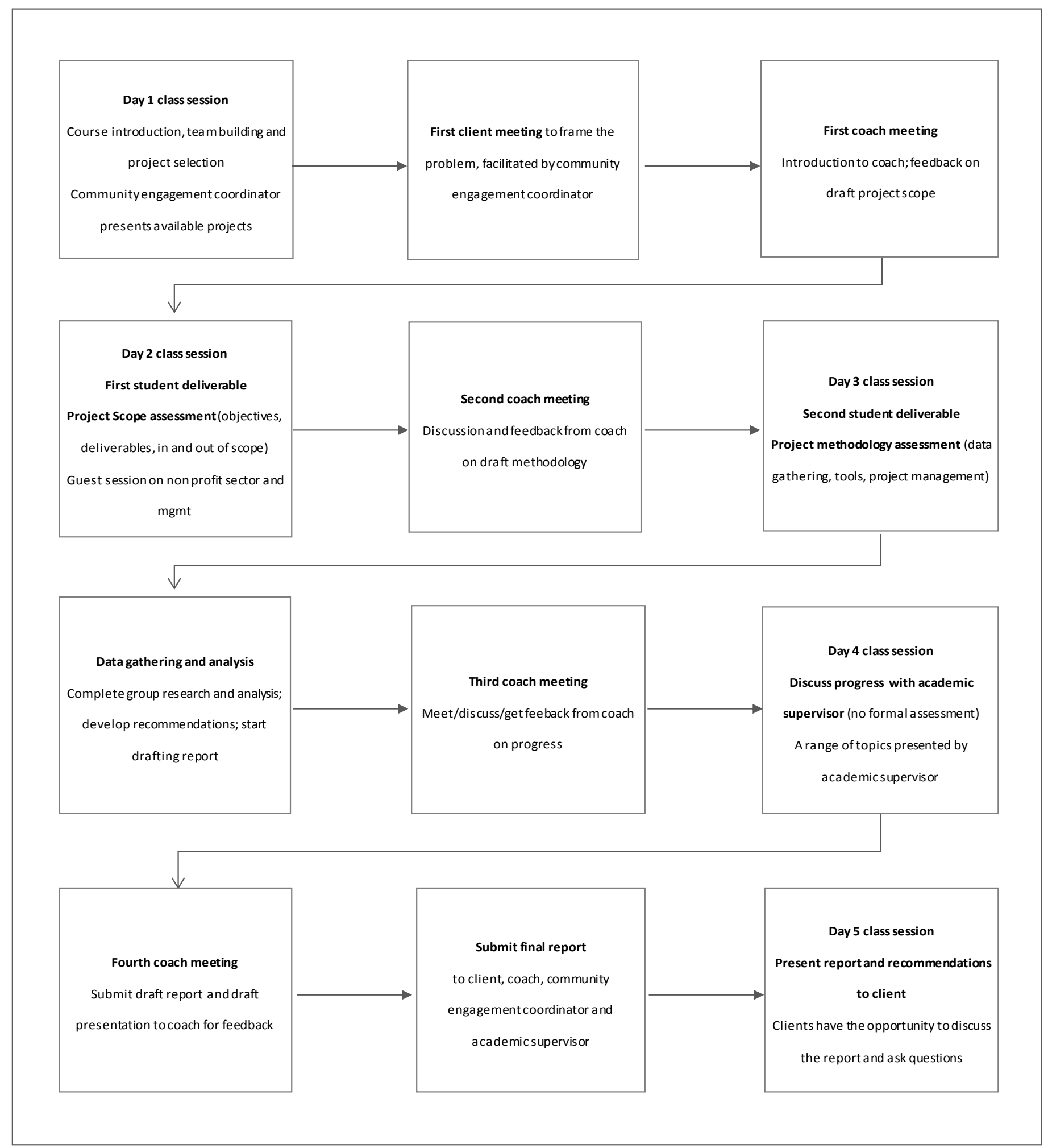


Table 1: Description of course process phases and elements

\begin{tabular}{|c|c|}
\hline $\begin{array}{l}\text { Process phases } \\
\text { and elements }\end{array}$ & Description and assessment \\
\hline \multicolumn{2}{|r|}{ Project initiation and community involvement } \\
\hline $\begin{array}{l}\text { Community- } \\
\text { initiated } \\
\text { projects }\end{array}$ & $\begin{array}{l}\text { Ensures real need and therefore real commitment from the community client to } \\
\text { the students' work and the project timeline. }\end{array}$ \\
\hline $\begin{array}{l}\text { Project scoping } \\
\text { and facilitation } \\
\text { of inputs }\end{array}$ & $\begin{array}{l}\text { The community engagement coordinator assists client organizations in } \\
\text { focusing the project and clarifying project goals. The university community- } \\
\text { engagement program provides continuity in the university’s partnerships with } \\
\text { communities, allowing larger, multi-disciplinary projects to be defined, } \\
\text { planned, broken down and completed across faculties and over time. }\end{array}$ \\
\hline $\begin{array}{l}\text { Project } \\
\text { breakdown and } \\
\text { clear roles and } \\
\text { responsibilities }\end{array}$ & $\begin{array}{l}\text { The community engagement coordinator ensures that projects are student- } \\
\text { ready and manageable within a } 13 \text {-week timeline and that students and } \\
\text { community organizations understand their roles and responsibilities. }\end{array}$ \\
\hline $\begin{array}{l}\text { Community } \\
\text { client } \\
\text { orientation } \\
\text { program }\end{array}$ & $\begin{array}{l}\text { Pre-semester, the community engagement coordinator requires clients to fill in } \\
\text { a project brief to help them develop the aims of the project, think about their } \\
\text { needs, target audiences and resources available for the project (e.g., time } \\
\text { commitment, personnel to assist the students). }\end{array}$ \\
\hline $\begin{array}{l}\text { Selection of } \\
\text { projects based } \\
\text { on specific }\end{array}$ & $\begin{array}{l}\text { The community engagement coordinator and the academic supervisor discuss } \\
\text { all project applications received and select projects based on four criteria: } \\
\text { a) the ability of the client to work with and support the students; }\end{array}$ \\
\hline
\end{tabular}




\begin{tabular}{|c|c|}
\hline criteria & $\begin{array}{l}\text { b) the significance of the project to the client organization; } \\
\text { c) the nature of the client organization; } \\
\text { d) the degree of interest the project has for students. }\end{array}$ \\
\hline $\begin{array}{l}\text { Confidentiality } \\
\text { within projects }\end{array}$ & $\begin{array}{l}\text { Students sign confidentiality agreements allowing client organizations to seek } \\
\text { advice for the most relevant issues including issues that are sensitive or } \\
\text { confidential. }\end{array}$ \\
\hline $\begin{array}{l}\text { Diverse range } \\
\text { of projects }\end{array}$ & $\begin{array}{l}\text { Diversity adds interest for the students as they see other projects developing } \\
\text { through various stages to completion. It also demands versatility in their } \\
\text { approach to planning for different clients and target audiences. }\end{array}$ \\
\hline $\begin{array}{l}\text { Clients attend } \\
\text { briefing and } \\
\text { presentation } \\
\text { events at the } \\
\text { university }\end{array}$ & $\begin{array}{l}\text { An important part of the project is the encouragement for community groups } \\
\text { and organizations to feel that the university contributes to the community and } \\
\text { is an inviting place to visit. As many see universities as 'closed' institutions, } \\
\text { this offer of free assistance can bridge many cultural and social barriers. }\end{array}$ \\
\hline \multicolumn{2}{|r|}{ Project process, tools and support } \\
\hline $\begin{array}{l}\text { Project team } \\
\text { formation }\end{array}$ & $\begin{array}{l}\text { Students are encouraged to learn as much about each other as possible during } \\
\text { the first session (through an activity called 'speed dating') and are then asked } \\
\text { to self-select team leaders, build teams and select projects based on their skill } \\
\text { set and interests. Students are then asked to assign additional roles to team } \\
\text { members, including client liaison, coach liaison and project manager based on } \\
\text { their strengths and prior experience. }\end{array}$ \\
\hline $\begin{array}{l}\text { Project } \\
\text { management }\end{array}$ & $\begin{array}{l}\text { Students are expected to manage their project effectively, to develop clear } \\
\text { individual roles and responsibilities, keep minutes of client meetings, and use }\end{array}$ \\
\hline
\end{tabular}




\begin{tabular}{|c|c|}
\hline $\begin{array}{l}\text { 13-week } \\
\text { timeline }\end{array}$ & online systems for communication and document development. \\
\hline Project scope & $\begin{array}{l}\text { The 'project scope' document is prepared by the student teams as the agreed } \\
\text { plan for actions and deliverables and is signed-off both by the academic } \\
\text { supervisor and community client. }\end{array}$ \\
\hline $\begin{array}{l}\text { Project } \\
\text { methodology }\end{array}$ & $\begin{array}{l}\text { The 'project methodology' represents the second part of a complete consulting } \\
\text { proposal and details what data will be gathered and the consulting methods, } \\
\text { frameworks and tools that will be used to deliver the project including project } \\
\text { management tools. This allows students to carefully consider relevant tools } \\
\text { and methods, plan division of responsibilities between team members and } \\
\text { receive feedback before commencing with data collection. }\end{array}$ \\
\hline $\begin{array}{l}\text { Project } \\
\text { monitoring }\end{array}$ & $\begin{array}{l}\text { The academic supervisor and community engagement coordinator monitor } \\
\text { progress and relationships during the semester. The student team is asked to } \\
\text { update the client organization regularly about the progress of their work. }\end{array}$ \\
\hline $\begin{array}{l}\text { Consulting } \\
\text { tools and } \\
\text { process }\end{array}$ & $\begin{array}{l}\text { The academic supervisor introduces teams to a range of relevant consulting } \\
\text { tools as well as to project management process, report writing and presentation } \\
\text { design. Teaching of consulting best practice including the consulting process, } \\
\text { tools and methodologies and the nature of the client-consultant interaction } \\
\text { enables students to learn about and apply consulting skills. }\end{array}$ \\
\hline $\begin{array}{l}\text { Formal } \\
\text { assessment and } \\
\text { feedback }\end{array}$ & $\begin{array}{l}\text { Formal feedback is provided during each of the scheduled sessions based on } \\
\text { submitted assessments or review of work in progress. Formal assessment takes } \\
\text { place in three stages spread over the semester, which are designed to resemble } \\
\text { periodic management reviews of a professional consulting engagement. As } \\
\text { part of the project scope assessment, students establish goals and objectives for }\end{array}$ \\
\hline
\end{tabular}




\begin{tabular}{|c|c|}
\hline & $\begin{array}{l}\text { their project which become benchmarks for students' final assessment. In the } \\
\text { methodology document, students develop a detailed project management plan } \\
\text { that allows them to self-regulate and assess their progress towards the final } \\
\text { assessment. The final report represents the major coursework assessment. } \\
\text { Students are also assessed on their presentation skills during the final } \\
\text { presentations. }\end{array}$ \\
\hline $\begin{array}{l}\text { Informal } \\
\text { feedback }\end{array}$ & $\begin{array}{l}\text { Frequent informal feedback is provided by the academic supervisor, the } \\
\text { community engagement coordinator, the client and the coaches. Such } \\
\text { extensive feedback maintains student motivation and responsiveness while } \\
\text { enabling students' autonomy. }\end{array}$ \\
\hline Self-assessment & $\begin{array}{l}\text { Students have the opportunity to self-assess their work for each of their } \\
\text { assessments enabling students to reflect upon their learning and their practice. } \\
\text { This stimulates the development of reflective-practitioners. It is also used as a } \\
\text { tool to enable students to define what value their work has generated for the } \\
\text { client. Self-assessment is discussed with the academic supervisor. }\end{array}$ \\
\hline $\begin{array}{l}\text { Two-way } \\
\text { feedback }\end{array}$ & $\begin{array}{l}\text { Students are encouraged to provide feedback to the academic supervisor which } \\
\text { alters the content of formal lectures and guest lectures to ensure that material } \\
\text { provided closes any knowledge and skill gaps and supports good performance. }\end{array}$ \\
\hline $\begin{array}{l}\text { Incorporation } \\
\text { of coaching and } \\
\text { industry expert } \\
\text { input }\end{array}$ & $\begin{array}{l}\text { The consulting coach acts as a sounding board for the student team offering } \\
\text { relevant consulting knowledge and expertise and providing additional } \\
\text { feedback to students. These interactions take place face-to-face where possible, } \\
\text { and via email, phone and Skype. }\end{array}$ \\
\hline $\begin{array}{l}\text { Several } \\
\text { meetings }\end{array}$ & $\begin{array}{l}\text { Interactions with community clients create opportunities for the students to } \\
\text { share what they have learnt in their degree and demonstrate they can apply }\end{array}$ \\
\hline
\end{tabular}




\begin{tabular}{|c|c|}
\hline $\begin{array}{l}\text { between client } \\
\text { and student } \\
\text { team }\end{array}$ & $\begin{array}{l}\text { their knowledge and skills appropriately when interacting with external parties. } \\
\text { This also ensures that knowledge and skills are transferred to the community } \\
\text { client. }\end{array}$ \\
\hline \multicolumn{2}{|r|}{ Report and presentation delivery } \\
\hline $\begin{array}{l}\text { Professional } \\
\text { presentations }\end{array}$ & $\begin{array}{l}\text { Student groups present their project to their community client, the academic } \\
\text { supervisor, client engagement coordinator, coach and invited guests during the } \\
\text { final presentation session. Students are assessed on the professionalism of this } \\
\text { presentation that includes explanation of the process, the final outcomes and an } \\
\text { outline of an implementation plan. }\end{array}$ \\
\hline $\begin{array}{l}\text { Final } \\
\text { assessment and } \\
\text { review }\end{array}$ & $\begin{array}{l}\text { Project reports represent the major coursework assessment. They are evaluated } \\
\text { based on their practical value and professional design and delivery. This } \\
\text { includes an assessment whether the recommendations are sound, relevant and } \\
\text { implementable and the quality of data gathering and analysis. Report structure, } \\
\text { logical flow and professional presentation are also taken into account. While } \\
\text { students are asked to complete individual sections of the report in order to be } \\
\text { assessed individually, they are strongly encouraged to prepare integrated } \\
\text { reports which flow seamlessly between sections. Integrated reports are always } \\
\text { assessed more positively than reports which lack coherence. }\end{array}$ \\
\hline $\begin{array}{l}\text { Engagement } \\
\text { beyond project }\end{array}$ & $\begin{array}{l}\text { Students are often enthused to help the community clients beyond the } 13 \text { week } \\
\text { project and some become volunteers or board members. }\end{array}$ \\
\hline $\begin{array}{l}\text { Communication } \\
\text { of value created } \\
\text { for the } \\
\text { university }\end{array}$ & $\begin{array}{l}\text { After each semester, the community engagement coordinator and the academic } \\
\text { supervisor calculate the value of the pro bono consulting work completed by } \\
\text { the student teams to demonstrate the extent to each the course contributes to } \\
\text { public good. This information is communicated to the university. Information }\end{array}$ \\
\hline
\end{tabular}




\begin{tabular}{|l|l|}
\hline $\begin{array}{l}\text { on the completed projects is included in the university's quality reporting, } \\
\text { including the annual report and Social Justice report, and the business school } \\
\text { report to the United Nations on the implementation of the Principles for } \\
\text { Responsible Management Education (UNPRME). Information about specific } \\
\text { projects is shared with the business school and university communication } \\
\text { offices and regularly used in internal and external publications. }\end{array}$ \\
\hline
\end{tabular}


Table 2: University student feedback survey results (2009-2015)

\begin{tabular}{|l|l|}
\hline $\begin{array}{l}\text { Survey statements 2009-2015 (N=176, response rate 56\%) } \\
\text { Note: A five point Likert-type scale with (1) being Strongly Disagree and (5) being } \\
\text { Strongly Agree was used in the survey }\end{array}$ & Mean/SD \\
\hline My learning experiences in this [course] were interesting and thought provoking. & $4.35 / 0.79$ \\
\hline This [course] was relevant to me. & $4.33 / 0.86$ \\
\hline \begin{tabular}{l} 
Overall I am satisfied with the quality of this [course]. \\
\hline Additional statements introduced in 2016 (N=37, response rate 57\%)
\end{tabular} & $4.24 / 0.83$ \\
\hline This [course] provided practical learning activities to develop new skills and \\
knowledge I may need in the workplace. & $4.70 / 0.58$ \\
\hline This [course] has developed my understanding of my intended profession. & $4.44 / 0.81$ \\
\hline
\end{tabular}


Table 3: Custom student feedback survey results (2006-2015)

\begin{tabular}{|l|l|}
\hline $\begin{array}{l}\text { Survey statements (N=171, response rate 42\%) } \\
\text { Note: A five point Likert-type scale with (1) being Strongly Disagree and (5) } \\
\text { being Strongly Agree was used in the survey }\end{array}$ & Mean/SD \\
\hline The project work was relevant to my professional development. & $4.3 / 0.92$ \\
\hline The project work was relevant to my personal development. & $4.3 / 0.87$ \\
\hline I would recommend Management Consulting projects to other & \\
\hline students. & $4.5 / 0.86$ \\
\hline
\end{tabular}


Table 4: Custom alumni feedback survey results (2006-2009)

\begin{tabular}{|l|l|}
\hline Survey statements (N=47, response rate 18\%) & \\
Note: A five point Likert-type scale with (1) being Strongly Disagree and (5) being Strongly & Mean/SD \\
Agree was used in the survey & $4.7 / 0.55$ \\
\hline The course developed my consulting skills. & $4.7 / 0.47$ \\
\hline The course provided valuable experience in working effectively with clients. & $4.7 / 0.60$ \\
\hline The course gave me a better appreciation of the real world applications of my & \\
\hline discipline. & $4.2 / 0.84$ \\
\hline The course provided a meaningful way to contribute to the community sector. & $4.6 / 0.72$ \\
\hline I gained greater understanding of the not-for-profit sector. & $4.4 / 0.75$ \\
\hline I gained awareness of other perspectives and cultures. & $4.2 / 0.89$ \\
\hline The experience strengthened my commitment to social responsibility. & \\
\hline
\end{tabular}


Table 5: Custom community client feedback survey results (2006-2015)

\begin{tabular}{|l|l|}
\hline Survey statements (N=56, response rate 75\%) & \\
Note: A five point Likert-type scale with (1) being Strongly Disagree and (5) being Strongly & Mean/SD \\
Agree was used in the survey & \\
\hline The project will be of value to our organisation. & $4.64 / 0.55$ \\
\hline The student(s) were professional in their approach. & $4.77 / 0.43$ \\
\hline The community engagement coordinator was of assistance in defining the project & $4.67 / .051$ \\
\hline and outcomes. & \\
\hline Working with the University on a project provided an opportunity for skills & $4.39 / 0.68$ \\
\hline exchange and skills development. & \\
\hline I would recommend doing a... project to other community organisations. & $4.96 / 0.19$ \\
\hline I would work with the University community engagement program again. & $4.91 / 0.29$ \\
\hline
\end{tabular}

